medRxiv preprint doi: https://doi.org/10.1101/2020.04.28.20082024; this version posted May 3, 2020. The copyright holder for this preprint (which was not certified by peer review) is the author/funder, who has granted medRxiv a license to display the preprint in perpetuity. It is made available under a CC-BY-NC-ND 4.0 International license.

\title{
Parechovirus infection in early childhood and association with subsequent celiac disease.
}

German Tapia, $\mathrm{PhD}^{1^{*}}$, Kateřina Chudá, MSc ${ }^{2 *}$, Christian R. Kahrs, MD, $\mathrm{PhD}^{3}$, Lars C. Stene, $\mathrm{PhD}^{1}$, Lenka Kramna, $\mathrm{PhD}^{2}$, Karl Mårild, MD, $\mathrm{PhD}^{4}$, Trond Rasmussen, MSc ${ }^{5}$, Kjersti S. Rønningen, $\mathrm{MD}, \mathrm{PhD}^{6}$, Ondřej Cinek, $\mathrm{MD}, \mathrm{PhD}^{2 \dagger}$, Ketil Størdal, $\mathrm{MD}, \mathrm{PhD}^{1,3 \dagger}$

* Shared first authorship; $\uparrow$ Shared last authorship

Short title: "Parechovirus and celiac disease"

\author{
Affiliations: \\ ${ }^{1}$ Department of Chronic Diseases and Ageing, Norwegian Institute of Public Health, Oslo, \\ Norway; \\ ${ }^{2}$ Department of Paediatrics, 2nd Faculty of Medicine, Charles University in Prague and \\ University Hospital Motol, Prague, Czech Republic; \\ ${ }^{3}$ Department of Pediatrics, Østfold Hospital Trust, Grålum, Norway; \\ ${ }^{4}$ Department of Pediatrics, Institute of Clinical Sciences, The Sahlgrenska Academy at \\ University of Gothenburg and Queen Silvia Children's Hospital, Gothenburg, Sweden; \\ ${ }^{5}$ Department of IT and e-health, Division of Institute Resources, Norwegian Institute of \\ Public Health, Oslo, Norway; \\ ${ }^{6}$ Department of Pediatric Research, Oslo University Hospital, Oslo, Norway
}

\author{
Abbreviations: CD, Celiac Disease; T1D, Type 1 Diabetes; OR, Odds Ratio; CI, Confidence \\ Interval; TG2, Transglutaminase 2.
}

Correspondence: German Tapia, Norwegian Institute of Public Health, P.O Box 222 Skøyen, 0213 Oslo, Norway. german.tapia@fhi.no. Telephone: 004721078410.

Keywords: Celiac disease; gluten; children; anellovirus; parechovirus; enterovirus; adenovirus.

Word count: Abstract 346, Manuscript 3376, Tables 3, Figures 1, References 43. (+ online-only supplement with 3 eTables and 5 eFigures) 
medRxiv preprint doi: https://doi.org/10.1101/2020.04.28.20082024; this version posted May 3, 2020. The copyright holder for this preprint (which was not certified by peer review) is the author/funder, who has granted medRxiv a license to display the preprint in perpetuity.

It is made available under a CC-BY-NC-ND 4.0 International license .

\section{Key points}

Question: Are parechovirus infections associated with development of celiac disease in childhood?

Findings: In this case-control study, nested in a cohort of children genetically at risk for celiac disease, a higher frequency of parechovirus gut infections (tested in monthly stool samples) were associated with later celiac disease. Coinfection with both parechovirus and enterovirus was associated with a markedly increased risk for later celiac disease.

Meaning: The association observed between parechovirus and future celiac disease, suggests that these common enteric infections could play a role in celiac disease development. 
medRxiv preprint doi: https://doi.org/10.1101/2020.04.28.20082024; this version posted May 3, 2020. The copyright holder for this preprint (which was not certified by peer review) is the author/funder, who has granted medRxiv a license to display the preprint in perpetuity.

It is made available under a CC-BY-NC-ND 4.0 International license .

\begin{abstract}
Importance: Celiac disease is an increasingly common immune-mediated disorder. The potential role of infections in celiac disease development is not well characterized.

Objective: To test whether two frequent enteric viruses, parechovirus and anellovirus, were associated with subsequent celiac disease. Our a priori hypothesis was that children who later developed celiac disease would have a higher frequency of parechovirus infections before transglutaminase 2 antibody development. Anellovirus testing was exploratory, as a potential marker of immune status.
\end{abstract}

Design: Matched case-control design nested within a longitudinal birth cohort (the MIDIA study) of children at genetic risk for celiac disease.

Setting: Children carrying the HLA genotype DR4-DQ8/DR3-DQ2, recruited at birth from the general population throughout Norway during 2001-2007.

Participants: Of 220 genetically at-risk children tested for celiac disease, 25 fulfilled the case criteria. Each case was matched for follow-up time, birthdate, and county of residence with two randomly selected children free from celiac disease (controls) from the cohort.

Exposures: Parechoviruses, the primary exposure, are infectious agents capable of replication at high virus loads. Anellovirus, previously proposed to reflect immune status, represent a ubiquitous viral exposure at low loads. Viruses were detected and quantified in monthly stool samples (collected from 3 through 35 months of age) using real-time PCR methods.

Main outcome and measures: Celiac disease diagnosis according to ESPGHAN 2012 criteria. We retrospectively tested blood samples taken at age 3, 6, 9, and 12 months, and then annually to determine when transglutaminase 2 antibodies developed.

Results: Parechovirus was detected in 222 of 2005 stool samples (11.1\%), and was more frequent in samples from cases before developing transglutaminase 2 antibodies (adjusted odds ratio [aOR] $1.67,95 \% \mathrm{CI} 1.14-2.45, \mathrm{P}=0.01)$. The odds ratio was higher when both 
medRxiv preprint doi: https://doi.org/10.1101/2020.04.28.20082024; this version posted May 3, 2020. The copyright holder for this preprint (which was not certified by peer review) is the author/funder, who has granted medRxiv a license to display the preprint in perpetuity.

It is made available under a CC-BY-NC-ND 4.0 International license.

parechovirus and enterovirus were positive in the same sample (aOR 4.73, 95\% CI 1.2617.67, $\mathrm{P}=0.02)$. Anellovirus was detected in 1540 of 1829 samples $(84.2 \%)$. Anellovirus status did not differ significantly between case and control subjects.

Conclusions and Relevance: Parechovirus infections in early life were associated with development of celiac disease in genetically at-risk children, suggesting a novel preventive target if confirmed in future studies. 
medRxiv preprint doi: https://doi.org/10.1101/2020.04.28.20082024; this version posted May 3, 2020. The copyright holder for this preprint

\section{INTRODUCTION}

Celiac disease $(\mathrm{CD})$ is an immune-mediated disease with known genetic background, known driver (gluten), but unknown environmental triggers.[1, 2] Identifying environmental triggers is challenging, as a subclinical phase detectable by transglutaminase 2 (TG2) antibodies usually precedes clinical CD diagnosis.[3, 4] The subclinical phase of CD can lead to reverse causality (e.g untreated CD might lead to increased infection), unless handled by study design.

One way to minimize reverse causality is using a longitudinal birth cohort, such as our Norwegian MIDIA (Norwegian acronym for environmental causes of type 1 diabetes) cohort. MIDIA recruited by HLA genotype predisposing to $\mathrm{CD}$, and was primarily designed to study type 1 diabetes (T1D) pathogenesis. CD and T1D have partly overlapping genetic risk, and could share environmental factors.[5, 6] Infections have long been a proposed environmental factor for T1D,[7] and previous studies suggest that infections may play a role in CD development. $[8,9,10,11,12,13]$ We previously performed a metagenomic virome survey of 291 stool samples from MIDIA (manuscript in preparation) to identify candidate human viruses in our population. Assessment of the literature and biological plausibility of the most frequent enteric viruses led us to focus on four major candidate viruses - enteroviruses, adenoviruses, parechoviruses and anelloviruses - which we wanted to study in detail using specific PCR methods. Enterovirus and adenovirus were investigated in a previous study, where we reported an association between human enterovirus and later CD risk.[14] The TEDDY study, a multinational birth cohort including children carrying high T1D risk HLADR-DQ genotypes with a similar longitudinal sampling schedule as MIDIA, recently corroborated the association between enterovirus and CD using a metagenomics approach. 
medRxiv preprint doi: https://doi.org/10.1101/2020.04.28.20082024; this version posted May 3, 2020. The copyright holder for this preprint

Parechoviruses are enteric viruses closely related to enteroviruses within the Picornaviridae family that frequently cause asymptomatic infections in young children.[16, 17] Clinical outcomes of parechovirus infection are uncommon, but can range from mild respiratory disease or gastroenteritis to meningitis, flaccid paralysis or sepsis.[17, 18, 19] An unrelated virus group present in low quantity in a large proportion of samples, the anelloviruses, are persistent human viruses with an unclear relation to disease,[20] but suggested to be associated with autoimmune disorders.[20, 21] Anellovirus is widely disseminated as replication seems linked to the immune system,[20,22] and could be a marker of immunocompetence.[23, 24, 25]

In this study, we used the MIDIA cohort to investigate if parechovirus and anellovirus frequency differed prior to TG2 antibodies in children later diagnosed with CD (cases) compared with matched controls. We also analyzed if specific genotypes, symptomatic infections or high viral loads were associated with $\mathrm{CD}$, and the influence of enterovirus, infant feeding and symptoms on possible associations. 
medRxiv preprint doi: https://doi.org/10.1101/2020.04.28.20082024; this version posted May 3, 2020. The copyright holder for this preprint (which was not certified by peer review) is the author/funder, who has granted medRxiv a license to display the preprint in perpetuity.

It is made available under a CC-BY-NC-ND 4.0 International license .

\section{METHODS}

We designed a nested case-control study of CD (details given in[14]) within a birth cohort originally designed to study T1D (MIDIA, described in[26]). Figure 1 outlines the study design and formation of the study sample. Characteristics of participants (shown in Table 1) were obtained from MIDIA questionnaires as described by Stene et al.[26] unless noted otherwise. MIDIA and the CD sub-study were approved by The Regional Committee for Medical Research ethics.

Briefly, during 2001-2007, 46939 newborns throughout Norway were screened for the HLADQ2/DQ8 genotype (HLA-DRB1*04:01-DQA1*03-DQB1*03:02/DQA1*05-DQB1*02) conferring an increased risk of T1D as well as CD. This genotype was identified in 912 (1.9\%) children, who were followed with repeated questionnaires, plasma samples (collected at ages 3, 6, 9, 12 months, then annually), and stool samples (monthly, ages 3-35 months). Children actively participating during 2014-2016 (n=501) were invited to CD screening ( $n=220$ consenting, Figure 1A). Those consenting tended to have higher prevalence of islet autoimmunity, fewer siblings, and slightly higher prevalence of CD family history at recruitment. Children with known $\mathrm{CD}(\mathrm{n}=13)$ were identified by parental questionnaire, followed by review of medical records. Consenting participants were screened for TG2 antibodies (using EliA Celikey IgA/EliA GliadinDP IgG, Thermo Fischer Scientific, Phadia AB; Uppsala, Sweden) in their most recent blood sample, detecting 12 additional children after diagnostic workup (in total 25 children with $\mathrm{CD}$ ). The $\mathrm{CD}$ diagnosis was based on ESPGHAN 2012 criteria. Briefly, these criteria require a biopsy with Marsh grade 2-3, or TG2-titers $>10 \mathrm{x}$ the normal upper limit, presence of endomysial antibodies in a separate blood sample and a HLA risk genotype. [27] Two controls per case were matched for follow-up duration, date of birth, and county of residence. One matched control was excluded owing to 
medRxiv preprint doi: https://doi.org/10.1101/2020.04.28.20082024; this version posted May 3, 2020. The copyright holder for this preprint (which was not certified by peer review) is the author/funder, who has granted medRxiv a license to display the preprint in perpetuity.

It is made available under a CC-BY-NC-ND 4.0 International license .

missing stool samples. Stored plasma samples from cases were screened for TG2 antibodies and antibodies against deamidated gliadin peptides (DGP), as per guidelines at the time, in order to identify the last negative and first positive sample for $\mathrm{CD}$ antibodies. The same testing was performed in controls to confirm the absence of CD. Children who were transiently positive for TG2 antibodies did not fulfill the case definition and were excluded as controls, with new random controls picked if necessary. No children were diagnosed based on DGP, and in practice TG2 antibodies was sufficient alone, with TG2 antibodies also defining the seroconversion interval. In the 25 case-control groups, 15 children with CD seroconverted before the end of stool sampling (35 months of age), while the remaining seroconverted at a later age.

\section{Detection of parechovirus and anellovirus in stool samples}

The studied viruses were Human parechovirus (species Parechovirus A; genus Parechovirus; family Picornaviridae, referred to as parechovirus hereinafter, a single strand positive (ss+)RNA virus), and the genera Alpha- and Beta- and Gammatorquevirus of the family Anelloviridae (referred to as anellovirus hereinafter, circular, negative sense, ssDNA viruses). As anellovirus is characteristic by its extreme genetic diversity, it was not investigated at species level or sequenced.[28] All available fecal samples from cases and controls were subjected to RNA and DNA extraction using Qiagen chemistry (Qiagen, Hilden, Germany). Parechovirus was tested ( $\mathrm{n}=2005$ samples) with real-time RT-PCR using primers based on Corless et al.[29] and a probe redesigned to detect novel parechovirus types. Anellovirus was tested ( $\mathrm{n}=1829$ samples) using real-time PCR adopted from Thom et al.[30]. Differences in number of tested samples was due to sample exhaustion. The positivity threshold was set to 10 copies $/ \mu \mathrm{L}$. The VP3-VP1 gene junction of parechovirus samples with $\geq 10$ copies $/ \mu \mathrm{L}$ was genotyped with next generation amplicon[31] or Sanger[32] sequencing. Oligonucleotide 
medRxiv preprint doi: https://doi.org/10.1101/2020.04.28.20082024; this version posted May 3, 2020. The copyright holder for this preprint

sequences used and details are given in the online-only supplement and eTable 1. Detailed protocols are available upon request.

\section{Statistical analysis}

\section{Main analysis}

We analyzed the association of virus with CD primarily by using a mixed effects logistic regression model with random intercepts for each child and for each matched set to account for the matched design. Virus positivity was the dependent variable (each virus a separate model) and case-control status an independent variable. The odds ratio (OR) for CD is then interpreted as the odds of a sample being virus positive given that it came from a case, compared with the same odds for virus positivity for samples from matched controls. Potential predictors of viral infection and $\mathrm{CD}$ were included as covariates in the main regression model: sex, age, age squared (to accommodate established non-linear associations between age and virus positivity), sample month, siblings (categorized as none, 1 , or $\geq 2$ ), and CD family history. The primary analysis included only samples collected before the last sample negative for TG2 antibodies (Figure 1C), to avoid potential reverse causality. The analyses were run in Stata, release 15 (StataCorp, College Station, Texas).

\section{Pre-planned secondary analyses}

We additionally adjusted the primary analysis for enterovirus positivity, islet autoimmunity, age at gluten introduction and breastfeeding duration, and stratified the analysis using only samples collected while breastfeeding or after weaning, and only before, after or during $( \pm 1$ month) gluten introduction. We analyzed the association between $\mathrm{CD}$ and parechovirus types present in $\geq 20$ samples. We investigated the association between virus and CD for stool samples collected during, and after development of TG2 antibodies. During seroconversion, 
medRxiv preprint doi: https://doi.org/10.1101/2020.04.28.20082024; this version posted May 3, 2020. The copyright holder for this preprint (which was not certified by peer review) is the author/funder, who has granted medRxiv a license to display the preprint in perpetuity.

It is made available under a CC-BY-NC-ND 4.0 International license .

we cannot determine if infections were prior or after appearance of TG2 antibodies. Analyzes after seroconversion was to determine if development of TG2 antibodies influenced infection frequency. We analyzed if high virus quantity ( $\geq$ median quantity of positive samples), longer viral shedding ( $\geq 2$ consecutive monthly samples), or symptomatic infections were associated with later CD. Data from our earlier study reporting an enterovirus-celiac disease association [14] was used to analyze possible confounding or mediation by enterovirus of the observed parechovirus-CD association and coinfections (samples positive for both viruses set as positive; other non-missing samples were set as negative, otherwise as the main analysis). To statistically adjust parechovirus results with our earlier data on enterovirus, we ran a conditional logistic regression including only data prior to development of TG2 antibodies with $\mathrm{CD}$ as outcome and number of parechovirus positive as exposure, adjusting for number of enterovirus positive samples, matching variables and covariates in the main analysis.

\section{Exploratory analyses}

As enterovirus and parechovirus are both picornaviruses, we combined these into one variable (positive for enterovirus or parechovirus), which was analysed as the main analysis. Recently, the TEDDY study reported results from a metagenomics survey, where infections were analysed by year of life $\left(1^{\text {st }}\right.$ and $\left.2^{\text {nd }}\right)$. [15] To attempt to replicate these results, we investigated the association between infections (enterovirus, parechovirus, adenovirus, and anellovirus) the first or second year of life and later celiac disease. These analyses was restricted to samples collected after the introduction of dietary gluten, and time of TG2 antibody development was set to the first positive sample (instead of the last negative, as otherwise in our manuscript) to replicate the TEDDY approach.[15] These analyses were adjusted for calendar month of sampling using sine and cosine terms, [33] due to low number of samples in these subanalyses, but otherwise adjusted as the main analysis. 
medRxiv preprint doi: https://doi.org/10.1101/2020.04.28.20082024; this version posted May 3, 2020. The copyright holder for this preprint (which was not certified by peer review) is the author/funder, who has granted medRxiv a license to display the preprint in perpetuity.

\section{RESULTS}

\section{Parechovirus is a frequent childhood viral exposure}

Parechovirus was detected in 222 of $2005(11.1 \%)$ tested stool samples in total, and was positive at least once in 72 out of $74(97.3 \%)$ tested children. The highest parechovirus quantity was $2.5 \times 10^{6}$ copies $/ \mu 1$ (median 1,979 copies $/ \mu 1$ in samples with $\geq 10$ copies $/ \mu 1$ ). Parechovirus was more common during September-January (eFigure 1), first encountered in early life (eFigure 2), and most frequent at 9-18 months of age (eFigure 3). The most common type was parechovirus $1(n=133,62.1 \%)$, followed by $6(n=55,30.2 \%), 3(n=21,11.5 \%)$ and $4(n=1,0.6 \%)$. A phylogenetic tree of parechovirus sequences is shown in eFigure 4 . The percentage of samples available at each collection age for this study are shown in eFigure 5.

\section{Parechovirus was more frequent in case children prior to TG2 antibodies}

Before development of TG2 antibodies the frequency of parechovirus positive samples was higher among cases (63/392 samples, $16.1 \%)$ than for matched control children (87/787 samples, $11.1 \%$ ), adjusted OR (aOR) of 1.67, 95\% CI 1.14-2.45, $\mathrm{P}=0.01$ (Table 2). Parechovirus 1 and 6 were more frequent in cases (Table 2). During or after development of TG2 antibodies, the frequency of parechovirus RNA in stool samples did not differ by case status (Table 2). Parechovirus positive samples concurrently ( \pm 15 days) of parent-reported diarrhea were more frequent in cases (6/384, compared to 5/780 samples in controls) prior to TG2 antibody development (aOR 3.90, 95\% CI 1.06-14.29, $\mathrm{P}=0.04$ ), but parechovirus positive samples with reported fever or common cold were not (data not shown). The frequency of high quantity or long-lasting parechovirus infections did not differ between case and control children (Table 2). 
medRxiv preprint doi: https://doi.org/10.1101/2020.04.28.20082024; this version posted May 3, 2020. The copyright holder for this preprint (which was not certified by peer review) is the author/funder, who has granted medRxiv a license to display the preprint in perpetuity.

It is made available under a CC-BY-NC-ND 4.0 International license .

Parechovirus and enterovirus were independently associated with later CD

Coinfection with enterovirus and parechovirus was observed in 10/427 case vs. 5/845 control samples (aOR 4.73, 95\% CI 1.26-17.67, $\mathrm{P}=0.02$ ). Adjusting for enterovirus in our main analysis gave similar estimates (aOR 1.81, 95\% CI 1.23-2.67, P=0.003), and adjusting our earlier reported enterovirus-celiac disease association for parechovirus did not substantially change our published results (aOR 1.76, 95\% CI 1.24-2.50, $\mathrm{P}=0.001)$. Using a conditional logistic regression model, parechovirus estimates did not change after statistical adjustment for enterovirus (aOR 1.71, 95\% CI 1.04-2.80 vs. aOR 1.69, 95\% CI 1.03-2.78 when additionally adjusted for enterovirus), suggesting independent associations. We assessed potential deviation from linearity by categorizing into approximate tertiles $(0,1-2$, and $\geq 3$ parechovirus positive samples before TG2 antibodies), in the conditional logistic regression model and found no evidence for deviation of additivity in the log odds (data not shown). Combining enterovirus and parechovirus into one variable (positive for either) gave similar results as in the main analysis (aOR $1.61,95 \%$ CI $1.19-2.17, \mathrm{p}=0.002)$.

\section{Secondary analyses did not substantially influence interpretation of results}

Adjusting our main analysis for breastfeeding, age at gluten introduction or islet autoimmunity did not change our results substantially (data not shown). Parechovirus infections after gluten introduction (median age 6 months, range 2-10), and while breastfed (median duration 12 months, range 1-23) were more frequent in case children (eTable 2).

\section{Anellovirus was asymptomatically present in a large majority of stools}

Anellovirus was present in all children, being positive in 1540 of $1829(84.2 \%)$ fecal samples. The longest continuous shedding of anellovirus was 32 months, and maximum quantity was 
medRxiv preprint doi: https://doi.org/10.1101/2020.04.28.20082024; this version posted May 3, 2020. The copyright holder for this preprint (which was not certified by peer review) is the author/funder, who has granted medRxiv a license to display the preprint in perpetuity.

It is made available under a CC-BY-NC-ND 4.0 International license .

238,773 copies/ $\mu 1$ (median 543 copies/ $\mu 1$ in positive samples). Anellovirus positivity did not show seasonality (data not shown) and was highly prevalent at all ages (eFigure 3).

Anellovirus frequency was not associated with seroconversion for TG2 antibodies

The frequency of anellovirus positive stool samples before or after development of TG2 antibodies did not differ significantly by case status. During development of TG2 antibodies (between the last negative and first positive TG2 antibody measurement), there was a borderline association, with cases having a higher frequency of positive samples $(92.5 \% \mathrm{vs}$ 83.4\%, aOR 3.32, 95\% CI 1.01-10.92, $\mathrm{P}=0.05$, Table 3). The frequency of anellovirus samples with high quantity did not differ between cases and controls (Table 3). Long-lasting anellovirus infections were not separately analyzed due to their persistent nature.

Anellovirus infections prior to, at the same time, or after gluten introduction, or while breastfed or after weaning, did not differ according to case status (eTable 2). The frequency of anellovirus positive samples with concurrent symptoms did not differ between case and control children (data not shown).

\section{Exploratory analyses stratified by year of life}

Samples positive for parechovirus were more common in case children the first year of life (aOR 3.09, 95\% CI 1.02 - 9.39, $\mathrm{p}=0.05$ ), and samples positive for enterovirus were more common in case children the second year of life (aOR 2.08, 95\% CI 1.33-3.27, $\mathrm{p}=0.001)$. Anellovirus and adenovirus did not show any statistically significant association with case status in the first or second year of life (eTable 3). 
medRxiv preprint doi: https://doi.org/10.1101/2020.04.28.20082024; this version posted May 3, 2020. The copyright holder for this preprint

(which was not certified by peer review) is the author/funder, who has granted medRxiv a license to display the preprint in perpetuity.

It is made available under a CC-BY-NC-ND 4.0 International license .

\section{DISCUSSION}

Case children were more likely to have parechovirus positive samples prior to the appearance of TG2 antibodies. This association did not seem to be confounded by enterovirus, or other variables considered.

\section{Strengths and limitations of the study}

The main strengths of the study are the longitudinal nature of the study and the careful construction of the case-control dataset. Screening of TG2 antibodies coupled with medical review and diagnostic workup, with widely accepted CD diagnostic criteria used for case definition makes the possibility of misclassification small. Testing for TG2 antibodies in stored blood samples allowed us to determine seroconversion interval and investigate infections prior to TG2 antibody development, thus minimizing potential spurious associations due to reverse causation. We observed no association with parechovirus positivity after TG2 antibody development, implying that CD autoimmunity does not influence parechovirus frequency. Another strength is how candidate viruses were selected. Enteric human candidate viruses were identified for quantitative PCR testing using metagenomic virome sequencing, ensuring that we could focus on frequent viruses present in the time period studied. We excluded less frequent viruses which could result in insufficient statistical power, and viruses without a plausible link to CD which could lead to multiple testing problems. PCR was the method of choice for assessing the viral exposure, as metagenomic sequencing is presently unsuitable for generating truly quantitative data. We adjusted for potential confounders, and are not aware of strong confounders neglected.

There are several limitations to this study. We lack data on host immune responses, such as cytokine and virus-specific antibody levels, which could be relevant for disease pathogenesis. 
medRxiv preprint doi: https://doi.org/10.1101/2020.04.28.20082024; this version posted May 3, 2020. The copyright holder for this preprint

Although we found statistically significant associations, and included a large number of samples, the modest number of children with CD led to limited precision in estimates. The smaller sample size in sub-analyzes must be kept in mind when evaluating these. Children in the MIDIA study all carry the HLA DR3-DQ2/DR4-DQ8 genotype, and we cannot generalize our results to subjects with other genotypes. However, DR3-DQ2 and DR4-DQ8 are the main CD HLA susceptibility genotypes, with the majority of CD cases carrying at least one of these. Children were followed up for $\sim 10$ years, and some could seroconvert or be diagnosed later, but most children are expected to develop CD antibodies by ten years of age.[34] All children were screened, and no control child developed CD antibodies during the study. As any observational study, we cannot rule out unmeasured or residual confounding, necessitating further prospective studies to replicate findings.

\section{Comparison with other studies}

One small prior study investigating parechovirus and CD did not detect any parechovirus measured in stool at 3 and 6 months of age.[35] In our data, parechovirus prevalence was very low in this age-group (e.g. $1.0 \%$ at $\leq 4$ months of age) which would limit statistical power for analyses restricted to this age-group.

We have previously reported an association between enterovirus and later CD.[14] A similar association with enterovirus was also recently reported in the second year of life in a large metagenomic study, which did not include parechovirus data.[15] To attempt to replicate results from the TEDDY study,[15] we did an exploratory analysis stratifying our analysis into the first and second year of life. We could not replicate the association reported between adenovirus infections the first year of life and later celiac disease autoimmunity.[15] Parechovirus was more frequent in samples from case children the first year of life, and 
medRxiv preprint doi: https://doi.org/10.1101/2020.04.28.20082024; this version posted May 3, 2020. The copyright holder for this preprint (which was not certified by peer review) is the author/funder, who has granted medRxiv a license to display the preprint in perpetuity. It is made available under a CC-BY-NC-ND 4.0 International license .

enterovirus was more frequent in samples from case children the second year of life. This could imply there are different risk periods for different viruses, or differences could be due to diet or development. Parechovirus and enterovirus are two of the most common human picornavirus genera, with overlapping presentation and seasonality, and both primarily replicate in epithelial cells of the intestinal mucosa and in adjacent lymphoid tissues.[17] As these viruses could presumably share infection risk factors, we tested whether our results were influenced by enterovirus, but parechovirus remained significantly associated with CD after adjustment for enterovirus. Interestingly, coinfection with both viruses associated with a highly increased CD risk, and both enterovirus and parechovirus presenting with diarrhea had increased risk estimates.[14]

There are no previous studies investigating anelloviruses and $\mathrm{CD}$, but the ubiquitous nature of anelloviruses makes the disease association difficult to interpret.[20] Anelloviruses are believed to replicate in stimulated peripheral blood mononuclear cells, so the presence or level of anellovirus could be a marker of already present disease or infection.[20, 22, 36, 37, 38, 39] A large majority of samples were positive for anellovirus. Yet, we cannot rule out that anellovirus could be a marker of underlying pathology, or disease progression, as in this study their occurrence was marginally increased during TG2 antibody seroconversion.

Studies on specific viral species have implicated members of Reoviridae[10, 13] and Picornaviridae $[14,15]$ in CD etiology. These observations and the present results could be interpreted to mean that infections with RNA viruses are associated with CD development, either in general, in these viral families, or in specific viral species/types/strains. Risk estimates varied between parechovirus types in our study, which could imply some - yet statistically insignificant - differences between parechovirus types regarding CD etiology, 
medRxiv preprint doi: https://doi.org/10.1101/2020.04.28.20082024; this version posted May 3, 2020. The copyright holder for this preprint

similar to the one shown for reovirus types in mouse models.[13] Picornavirus infections have been hypothesized to be involved in autoimmunity,[40] and could contribute to CD development in several ways. Infections could disrupt the mucosal barrier, leading to translocation of gluten peptides into the mucosa,[41] tissue injury and/or inflammation which could provide signals necessary for breaking tolerance against gluten peptides, and/or activate gluten-specific CD4 ${ }^{+}$T-cells.[2] Infection with RNA viruses could activate extracellular TG2,[42] leading to increased gluten deamidation at the site of a viral infection, where it could be taken up, processed and presented by antigen-presenting cells concurrently with viral proteins. Viral infections are thus biologically plausible environmental factors, but mechanistic studies are needed to elucidate potential mechanisms.

\section{Implications, Conclusions and future work}

These results could imply that parechovirus infections are associated with increased risk of CD. Picornavirus infections could be one of several environmental factors associated with increased risk for development of CD. Our findings suggest novel preventive targets if corroborated in future studies. 
medRxiv preprint doi: https://doi.org/10.1101/2020.04.28.20082024; this version posted May 3, 2020. The copyright holder for this preprint (which was not certified by peer review) is the author/funder, who has granted medRxiv a license to display the preprint in perpetuity. It is made available under a CC-BY-NC-ND 4.0 International license .

\section{ACKNOWLEDGEMENTS}

Author contributions: Conceived and designed the study: CRK GT OC LCS KS. Virus detection and genotyping: OC KC LK. Analyzed the data: GT LCS. Contributed reagents/materials/analysis tools: GT OC KS. Drafted the first version of the paper: GT. Reviewed, commented and revised the paper: All authors. Data access: Sequences from this study are deposited in GenBank, accession numbers MT009645-MT009897. Disclosures: The authors have no conflicts of interest relevant to this article to disclose. Grant support: This work was supported by The Research Council of Norway (grant numbers 205086/F20 to GT, 166515/V50 to KSR), and the Project for the Conceptual Development of Research Organization 00064203 (University Hospital Motol, Prague, Czech Republic). Kateřina Chudá has been supported with funding from the European Union Horizon 2020 research and innovation programme under grant agreement No 874864 HEDIMED. Christian Riddervold Kahrs has been supported with grants from Østfold Hospital Trust, Kalnes, Norway. The EliA Celikey and EliA Gliadin kits were supported by Thermo Fisher Scientific, Norway. The funders had no role in study design, data collection and analysis, decision to publish, or preparation of the manuscript. Acknowledgments: We express our sincere gratitude to the participants in the MIDIA cohort. We also especially thank Nicolai Andre Lund-Blix of Oslo University Hospital, Norway, for his help with the breastfeeding data and discussions; Lisa Merete Markussen of Akershus University Hospital for help with analyzing celiac disease antibodies in historical blood samples; Kaja Klykken Aas and Nina Stensrud from the Norwegian Institute of Public Health for handling plasma and stool samples in the MIDIA project; and the public health nurses in the MIDIA project (Asbjørg Skorge Hornseth, Liv Kjeldstadli Onsrud, and Turid Wetlesen). 
medRxiv preprint doi: https://doi.org/10.1101/2020.04.28.20082024; this version posted May 3, 2020. The copyright holder for this preprint (which was not certified by peer review) is the author/funder, who has granted medRxiv a license to display the preprint in perpetuity. It is made available under a CC-BY-NC-ND 4.0 International license .

\section{References}

$1 \quad$ Green PH, Cellier C. Celiac disease. N Engl J Med 2007;357:1731-43.

2 Sollid LM, Jabri B. Triggers and drivers of autoimmunity: lessons from coeliac disease. Nat Rev Immunol 2013;13:294-302.

3 Abadie V, Sollid LM, Barreiro LB, Jabri B. Integration of genetic and immunological insights into a model of celiac disease pathogenesis. Annual Review of Immunology 2011;29:493-525.

4 Agardh D, Lee HS, Kurppa K, Simell V, Aronsson CA, Jorneus O, et al. Clinical features of celiac disease: a prospective birth cohort. Pediatrics 2015;135:627-34.

$5 \quad$ Verdu EF, Danska JS. Common ground: shared risk factors for type 1 diabetes and celiac disease. Nat Immunol 2018;19:685-95.

$6 \quad$ Kurppa K, Laitinen A, Agardh D. Coeliac disease in children with type 1 diabetes. Lancet Child Adolesc Health 2018;2:133-43.

$7 \quad$ Hyoty H. Viruses in type 1 diabetes. Pediatr Diabetes 2016;17 Suppl 22:56-64.

8 Mårild K, Kahrs CR, Tapia G, Stene LC, Størdal K. Infections and Risk of Celiac Disease in Childhood: A Prospective Nationwide Cohort Study. Am J Gastroenterol 2015;110:1475-84.

9 Kemppainen KM, Lynch KF, Liu E, Lonnrot M, Simell V, Briese T, et al. Factors That Increase Risk of Celiac Disease Autoimmunity After a Gastrointestinal Infection in Early Life. Clin Gastroenterol Hepatol 2017;15:694-702 e5.

10 Stene LC, Honeyman MC, Hoffenberg EJ, Haas JE, Sokol RJ, Emery L, et al. Rotavirus Infection Frequency and Risk of Celiac Disease Autoimmunity in Early Childhood: A Longitudinal Study. Am J Gastroenterol 2006;101:2333-40.

11 Jansen MA, van den Heuvel D, van der Zwet KV, Jaddoe VW, Hofman A, Escher JC, et al. Herpesvirus Infections and Transglutaminase Type 2 Antibody Positivity in Childhood: The Generation R Study. J Pediatr Gastroenterol Nutr 2016;63:423-30.

12 Beyerlein A, Donnachie E, Ziegler AG. Infections in Early Life and Development of Celiac Disease. Am J Epidemiol 2017;186:1277-80.

13 Bouziat R, Hinterleitner R, Brown JJ, Stencel-Baerenwald JE, Ikizler M, Mayassi T, et al. Reovirus infection triggers inflammatory responses to dietary antigens and development of celiac disease. Science 2017;356:44-50.

14 Kahrs CR, Chuda K, Tapia G, Stene LC, Marild K, Rasmussen T, et al. Enterovirus as trigger of coeliac disease: nested case-control study within prospective birth cohort. BMJ 2019;364:1231.

15 Lindfors K, Lin J, Lee HS, Hyoty H, Nykter M, Kurppa K, et al. Metagenomics of the faecal virome indicate a cumulative effect of enterovirus and gluten amount on the risk of coeliac disease autoimmunity in genetically at risk children: the TEDDY study. Gut 2019.

16 Tapia G, Cinek O, Witso E, Kulich M, Rasmussen T, Grinde B, et al. Longitudinal observation of parechovirus in stool samples from Norwegian infants. J Med Virol 2008;80:1835-42.

17 de Crom SC, Rossen JW, van Furth AM, Obihara CC. Enterovirus and parechovirus infection in children: a brief overview. Eur J Pediatr 2016;175:1023-9.

18 de Crom SC, Rossen JW, de Moor RA, Veldkamp EJ, van Furth AM, Obihara CC. Prospective assessment of clinical symptoms associated with enterovirus and parechovirus genotypes in a multicenter study in Dutch children. J Clin Virol 2016;77:15-20.

19 Harvala H, Simmonds P. Human parechoviruses: biology, epidemiology and clinical significance. J Clin Virol 2009;45:1-9.

20 Spandole S, Cimponeriu D, Berca LM, Mihaescu G. Human anelloviruses: an update of molecular, epidemiological and clinical aspects. Arch Virol 2015;160:893-908.

21 Maximova N, Pizzol A, Ferrara G, Maestro A, Tamaro P. Does Teno Torque Virus Induce Autoimmunity After Hematopoietic Stem Cell Transplantation? A Case Report. J Pediatr Hematol Oncol 2015;37:e194-7.

22 Maggi F, Fornai C, Zaccaro L, Morrica A, Vatteroni ML, Isola P, et al. TT virus (TTV) loads associated with different peripheral blood cell types and evidence for TTV replication in activated mononuclear cells. J Med Virol 2001;64:190-4. 
medRxiv preprint doi: https://doi.org/10.1101/2020.04.28.20082024; this version posted May 3, 2020. The copyright holder for this preprint (which was not certified by peer review) is the author/funder, who has granted medRxiv a license to display the preprint in perpetuity. It is made available under a CC-BY-NC-ND 4.0 International license .

23 Focosi D, Antonelli G, Pistello M, Maggi F. Torquetenovirus: the human virome from bench to bedside. Clin Microbiol Infect 2016;22:589-93.

24 Tan SK, Relman DA, Pinsky BA. The Human Virome: Implications for Clinical Practice in Transplantation Medicine. J Clin Microbiol 2017;55:2884-93.

25 Siqueira JD, Curty G, Xutao D, Hofer CB, Machado ES, Seuanez HN, et al. Composite Analysis of the Virome and Bacteriome of HIV/HPV Co-Infected Women Reveals Proxies for Immunodeficiency. Viruses 2019;11.

26 Stene LC, Witso E, Torjesen PA, Rasmussen T, Magnus P, Cinek O, et al. Islet autoantibody development during follow-up of high-risk children from the general Norwegian population from three months of age: design and early results from the MIDIA study. Journal of Autoimmunity 2007;29:44-51.

27 Husby S, Koletzko S, Korponay-Szabò IR, Mearin ML, Phillips A, Shamir R, et al. European Society for Pediatric Gastroenterology, Hepatology, and Nutrition guidelines for the diagnosis of coeliac disease. J Pediatr Gastroenterol Nutr 2012;54:136-60.

28 Freer G, Maggi F, Pifferi M, Di Cicco ME, Peroni DG, Pistello M. The Virome and Its Major Component, Anellovirus, a Convoluted System Molding Human Immune Defenses and Possibly Affecting the Development of Asthma and Respiratory Diseases in Childhood. Front Microbiol 2018;9:686.

29 Corless CE, Guiver M, Borrow R, Edwards-Jones V, Fox AJ, Kaczmarski EB, et al. Development and evaluation of a 'real-time' RT-PCR for the detection of enterovirus and parechovirus RNA in CSF and throat swab samples. J Med Virol 2002;67:555-62.

30 Thom K, Morrison C, Lewis JC, Simmonds P. Distribution of TT virus (TTV), TTV-like minivirus, and related viruses in humans and nonhuman primates. Virology 2003;306:324-33.

31 Cinek O, Kramna L, Mazankova K, Kunteova K, Chuda K, E CJC, et al. Virus genotyping by massive parallel amplicon sequencing: adenovirus and enterovirus in the Norwegian MIDIA study. J Med Virol 2019;91:606-14.

32 Harvala H, Robertson I, McWilliam Leitch EC, Benschop K, Wolthers KC, Templeton K, et al. Epidemiology and clinical associations of human parechovirus respiratory infections. J Clin Microbiol 2008;46:3446-53.

33 Barnett AG, Dobson AJ. Cosinor. Analysing Seasonal Health Data. New York: Springer Verlag Berlin Heidelberg, 2010.

34 Liu E, Dong F, Baron AE, Taki I, Norris JM, Frohnert Bl, et al. High Incidence of Celiac Disease in a Long-term Study of Adolescents With Susceptibility Genotypes. Gastroenterology

2017;152:1329-36 e1.

35 Simre K, Uibo O, Peet A, Puustinen L, Oikarainen S, Tamminen K, et al. Early-life exposure to common virus infections did not differ between coeliac disease patients and controls. Acta Paediatr 2019.

36 Biagini P, Gallian P, Cantaloube JF, Attoui $\mathrm{H}$, de Micco P, de Lamballerie X. Distribution and genetic analysis of TTV and TTMV major phylogenetic groups in French blood donors. J Med Virol 2006;78:298-304.

37 Takahashi M, Asabe S, Gotanda Y, Kishimoto J, Tsuda F, Okamoto H. TT virus is distributed in various leukocyte subpopulations at distinct levels, with the highest viral load in granulocytes.

Biochem Biophys Res Commun 2002;290:242-8.

38 Mariscal LF, Lopez-Alcorocho JM, Rodriguez-Inigo E, Ortiz-Movilla N, de Lucas S, Bartolome J, et al. TT virus replicates in stimulated but not in nonstimulated peripheral blood mononuclear cells. Virology 2002;301:121-9.

39 Maggi F, Tempestini E, Lanini L, Andreoli E, Fornai C, Giannecchini S, et al. Blood levels of TT virus following immune stimulation with influenza or hepatitis B vaccine. J Med Virol 2005;75:358-65.

40 Massilamany C, Koenig A, Reddy J, Huber S, Buskiewicz I. Autoimmunity in picornavirus infections. Curr Opin Virol 2016;16:8-14.

41 Schumann M, Siegmund B, Schulzke JD, Fromm M. Celiac Disease: Role of the Epithelial Barrier. Cell Mol Gastroenterol Hepatol 2017;3:150-62. 
medRxiv preprint doi: https://doi.org/10.1101/2020.04.28.20082024; this version posted May 3, 2020. The copyright holder for this preprint (which was not certified by peer review) is the author/funder, who has granted medRxiv a license to display the preprint in perpetuity.

It is made available under a CC-BY-NC-ND 4.0 International license.

42 Siegel M, Strnad P, Watts RE, Choi K, Jabri B, Omary MB, et al. Extracellular transglutaminase 2 is catalytically inactive, but is transiently activated upon tissue injury. PLoS One 2008;3:e1861.

43 Weiner J. riverplot: Sankey or Ribbon Plots. (R Package). Weiner, January, 2017. 
medRxiv preprint doi: https://doi.org/10.1101/2020.04.28.20082024; this version posted May 3, 2020. The copyright holder for this preprint (which was not certified by peer review) is the author/funder, who has granted medRxiv a license to display the preprint in perpetuity.

It is made available under a CC-BY-NC-ND 4.0 International license .

Table 1. Characteristics of the study participants

\begin{tabular}{|c|c|c|}
\hline & Cases $(n=25)$ & Controls $(n=49)$ \\
\hline Girls (n (\%)) & $16(64)$ & $26(53)$ \\
\hline \multicolumn{3}{|l|}{ Other children in household $(\mathrm{n}(\%))^{0}$} \\
\hline None & $7(28)$ & $15(31)$ \\
\hline 1 & $10(40)$ & $28(57)$ \\
\hline$\geq 2$ & $8(32)$ & $6(12)$ \\
\hline Islet autoimmunity $(\mathrm{n}(\%))^{\mathrm{a}}$ & $4(16)$ & $1(2)$ \\
\hline Family history of celiac disease $^{\mathrm{b}}$ & $7(28)$ & $4(8)$ \\
\hline Mean (SD) age (months) at antibody screening test ${ }^{\mathrm{c}}$ & $99(30)$ & $106(21)$ \\
\hline Mean (range) age (months) of last antibody negative sample & $30(6-75)$ & n.a \\
\hline Mean (SD) age (months) at end of study ${ }^{\mathrm{d}}$ & $119(19)$ & $119(19)$ \\
\hline Mean (SD) age (months) at last stool sample & $32(7)$ & $34(3)$ \\
\hline Stool samples ${ }^{\mathrm{e}}$ & 703 & 1458 \\
\hline \multicolumn{3}{|l|}{ Parechovirus } \\
\hline Stool samples with parechovirus data (n (\%)) & $647(92)$ & $1358(93)$ \\
\hline Parechovirus positivef stool samples (n (\%)) & $84(13.0)$ & $138(10.2)$ \\
\hline Median (range) count of positive samples per child & $3(1-6)$ & $3(0-8)$ \\
\hline \multicolumn{3}{|l|}{ Anellovirus } \\
\hline Stool samples with anellovirus data $(n(\%))$ & $588(85)$ & $1241(84)$ \\
\hline Anellovirus positivef samples $(n(\%))$ & $506(86)$ & $1034(83)$ \\
\hline Median(range) count of positive samples per child & $22(5-31)$ & $21(10-32)$ \\
\hline
\end{tabular}

${ }^{0}$ No children in the matched case-control set were cousins, half siblings or siblings to each other.

${ }^{\text {a }}$ Determined as described in Stene et al.[26]

${ }^{\mathrm{b}}$ Known celiac disease in first degree relative or half-sibling ascertained at celiac disease screening 2014-2016.

${ }^{\mathrm{c}}$ Antibody screening test performed on the most recent blood sample from both case and control children at time of inclusion in celiac disease sub-study of MIDIA

${ }^{\mathrm{d}}$ At time when all 25 cases were ascertained by end of February 2016.

${ }^{\mathrm{e}}$ Discrepancy between total number of stool samples, and samples providing virus data was due to missing samples or failed laboratory test.

${ }^{\mathrm{f}}$ Positivity defined as $\geq 10$ copies of viral genomes per $\mu 1$ 
medRxiv preprint doi: https://doi.org/10.1101/2020.04.28.20082024; this version posted May 3, 2020. The copyright holder for this preprint (which was not certified by peer review) is the author/funder, who has granted medRxiv a license to display the preprint in perpetuity.

It is made available under a CC-BY-NC-ND 4.0 International license .

Table 2. Association between parechovirus and celiac disease ${ }^{a}$

\begin{tabular}{|c|c|c|c|c|c|}
\hline \multirow[t]{2}{*}{ Parechovirus } & Cases & & \multirow{2}{*}{$\begin{array}{c}\text { Unadjusted } \\
\text { Odds ratio } \\
\text { (95\% CI) } \\
\end{array}$} & \multicolumn{2}{|c|}{ Adjusted $^{b}$} \\
\hline & \multicolumn{2}{|c|}{$\begin{array}{l}\text { Positives }(n) / \text { Total } \\
(N) \text { samples }(\%)\end{array}$} & & $\begin{array}{l}\text { Odds ratio } \\
(95 \% \mathrm{CI})\end{array}$ & $\begin{array}{c}\mathbf{P} \\
\text { value }\end{array}$ \\
\hline \multicolumn{6}{|l|}{ Main analysis ${ }^{\mathrm{c}}$} \\
\hline $\begin{array}{l}\text { Parechovirus, before TG2 antibody } \\
\text { seroconversion }\end{array}$ & $\begin{array}{c}63 / 392 \\
(16.1 \%)\end{array}$ & $\begin{array}{c}87 / 787 \\
(11.1 \%)\end{array}$ & $1.57(1.07-2.28)$ & $1.67(1.14-2.45)$ & 0.01 \\
\hline \multicolumn{6}{|l|}{ Secondary analyses } \\
\hline $\begin{array}{l}\text { Parechovirus, during TG2 antibody } \\
\text { seroconversion }\end{array}$ & $\begin{array}{l}12 / 136 \\
(8.8 \%)\end{array}$ & $\begin{array}{l}31 / 320 \\
(9.7 \%)\end{array}$ & $0.89(0.44-1.81)$ & $1.12(0.48-2.60)$ & 0.79 \\
\hline $\begin{array}{l}\text { Parechovirus, after TG2 antibody } \\
\text { seroconversion }\end{array}$ & $\begin{array}{c}9 / 119 \\
(7.6 \%)\end{array}$ & $\begin{array}{l}20 / 251 \\
(8.0 \%)\end{array}$ & $0.96(0.42-2.22)$ & $1.04(0.40-2.70)$ & 0.94 \\
\hline $\begin{array}{l}\text { Parechovirus } 1 \text {, before TG2 } \\
\text { antibody seroconversion }\end{array}$ & $\begin{array}{l}31 / 360 \\
(8.6 \%)\end{array}$ & $\begin{array}{l}47 / 747 \\
(6.3 \%)\end{array}$ & $1.40(0.88-2.25)$ & $1.42(0.84-2.39)$ & 0.19 \\
\hline $\begin{array}{l}\text { Parechovirus } 6 \text {, before TG2 } \\
\text { antibody seroconversion }\end{array}$ & $\begin{array}{l}18 / 347 \\
(5.2 \%)\end{array}$ & $\begin{array}{l}22 / 722 \\
(3.0 \%)\end{array}$ & $1.80(0.87-3.73)$ & $1.87(0.88-3.97)$ & 0.10 \\
\hline $\begin{array}{l}\text { Parechovirus, long }{ }^{\mathrm{d}} \text { infections } \\
\text { before TG } 2 \text { antibody } \\
\text { seroconversion }\end{array}$ & $\begin{array}{l}21 / 350 \\
(6.0 \%)\end{array}$ & $\begin{array}{l}30 / 730 \\
(4.1 \%)\end{array}$ & $1.49(0.84-2.64)$ & $1.54(0.83-2.86)$ & 0.18 \\
\hline $\begin{array}{l}\text { Parechovirus, high }{ }^{\mathrm{e}} \text { quantity before } \\
\text { TG2 antibody seroconversion }\end{array}$ & $\begin{array}{l}33 / 392 \\
(8.4 \%)\end{array}$ & $\begin{array}{l}48 / 787 \\
(6.1 \%)\end{array}$ & $1.42(0.89-2.24)$ & $1.41(0.85-2.35)$ & 0.19 \\
\hline
\end{tabular}

${ }^{\text {a }}$ The number of positive/total stool samples included in each analysis (for the cases and controls) and the results from the mixed effects logistic regression. In total, there were 222 positive samples, with 150 before, 43 during and 29 after TG2 antibody seroconversion. In the analysis for the specific genotypes, samples positive for other parechovirus types have been set to missing.

${ }^{\mathrm{b}}$ Adjusted for sex, age, age squared, month of sample collection, number of siblings, and family history of celiac disease.

${ }^{\mathrm{c}}$ Before: prior to last TG2 antibody negative blood sample. During: between the last TG2 antibody negative and the first TG2 antibody positive blood sample. After: after the first TG2 antibody positive blood sample.

${ }^{\mathrm{d}}$ Defined as infections lasting $\geq 2$ months

${ }^{\mathrm{e}}$ Defined as $\geq$ median quantity $(\geq 1979$ copies/ $\mu$ l) of parechovirus positive samples 
medRxiv preprint doi: https://doi.org/10.1101/2020.04.28.20082024; this version posted May 3, 2020. The copyright holder for this preprint (which was not certified by peer review) is the author/funder, who has granted medRxiv a license to display the preprint in perpetuity.

It is made available under a CC-BY-NC-ND 4.0 International license .

Table 3. Association between anellovirus with celiac disease ${ }^{a}$

\begin{tabular}{|c|c|c|c|c|c|}
\hline \multirow[t]{2}{*}{ Anellovirus } & $\begin{array}{c}\text { Cases } \\
(n=25)\end{array}$ & $\begin{array}{c}\text { Control } \\
s \\
(n=49) \\
\end{array}$ & \multirow{2}{*}{$\begin{array}{c}\text { Unadjusted } \\
\text { Odds ratio } \\
(95 \% \mathrm{CI}) \\
\end{array}$} & \multicolumn{2}{|l|}{ Adjusted $^{b}$} \\
\hline & \multicolumn{2}{|c|}{$\begin{array}{l}\text { Positives }(n) / \text { Total } \\
(N) \text { samples }(\%)\end{array}$} & & $\begin{array}{l}\text { Odds ratio } \\
(95 \% \mathrm{CI})\end{array}$ & $\begin{array}{c}\mathbf{P} \\
\text { value }\end{array}$ \\
\hline \multicolumn{6}{|l|}{ Main analysis ${ }^{\mathrm{c}}$} \\
\hline Anellovirus & $\begin{array}{l}331 / 376 \\
(88.0 \%)\end{array}$ & $\begin{array}{l}645 / 758 \\
(85.1 \%)\end{array}$ & $1.28(0.61-2.71)$ & $1.39(0.64-3.03)$ & 0.40 \\
\hline \multicolumn{6}{|l|}{ Secondary analyses } \\
\hline $\begin{array}{l}\text { Anellovirus, high }{ }^{\mathrm{d}} \text { quantity before } \\
\text { TG2 antibodies }\end{array}$ & $\begin{array}{c}188 / 376 \\
(50 \%)\end{array}$ & $\begin{array}{l}325 / 758 \\
(42.9 \%)\end{array}$ & $1.37(0.51-0.94)$ & $1.41(0.92-2.15)$ & 0.11 \\
\hline $\begin{array}{l}\text { Anellovirus, during TG2 antibody } \\
\text { seroconversion }\end{array}$ & $\begin{array}{c}99 / 107 \\
(92.5 \%)\end{array}$ & $\begin{array}{l}216 / 259 \\
(83.4 \%)\end{array}$ & $2.50(0.79-7.86)$ & $\begin{array}{l}3.32(1.01- \\
10.92)\end{array}$ & 0.05 \\
\hline $\begin{array}{l}\text { Anellovirus, after TG2 antibody } \\
\text { seroconversion }\end{array}$ & $\begin{array}{c}76 / 105 \\
(72.4 \%)\end{array}$ & $\begin{array}{l}173 / 224 \\
(77.2 \%)\end{array}$ & $0.75(0.32-1.78)$ & $0.92(0.36-2.36)$ & 0.86 \\
\hline
\end{tabular}

${ }^{\text {a }}$ The number of positive/total stool samples included in each analysis (for the cases and controls) and the results from the mixed effects logistic regression are shown. In total, there were 976 positive samples prior to, 315 during and 249 after TG2 antibody seroconversion. ${ }^{\mathrm{b}}$ Adjusted for sex, age, age squared, month of sample collection, number of siblings, and family history of celiac disease.

${ }^{\mathrm{c}}$ Before: prior to last celiac disease antibody negative blood sample. During: between the last celiac disease antibody negative and the first celiac disease antibody positive blood sample.

After: after the first celiac disease antibody positive blood sample.

${ }^{\mathrm{d} \mid}$ Defined as $\geq$ median quantity $(543$ copies $/ \mu \mathrm{l})$ in anellovirus positive samples 
Figure 1: Study design.

\section{A Flowchart}

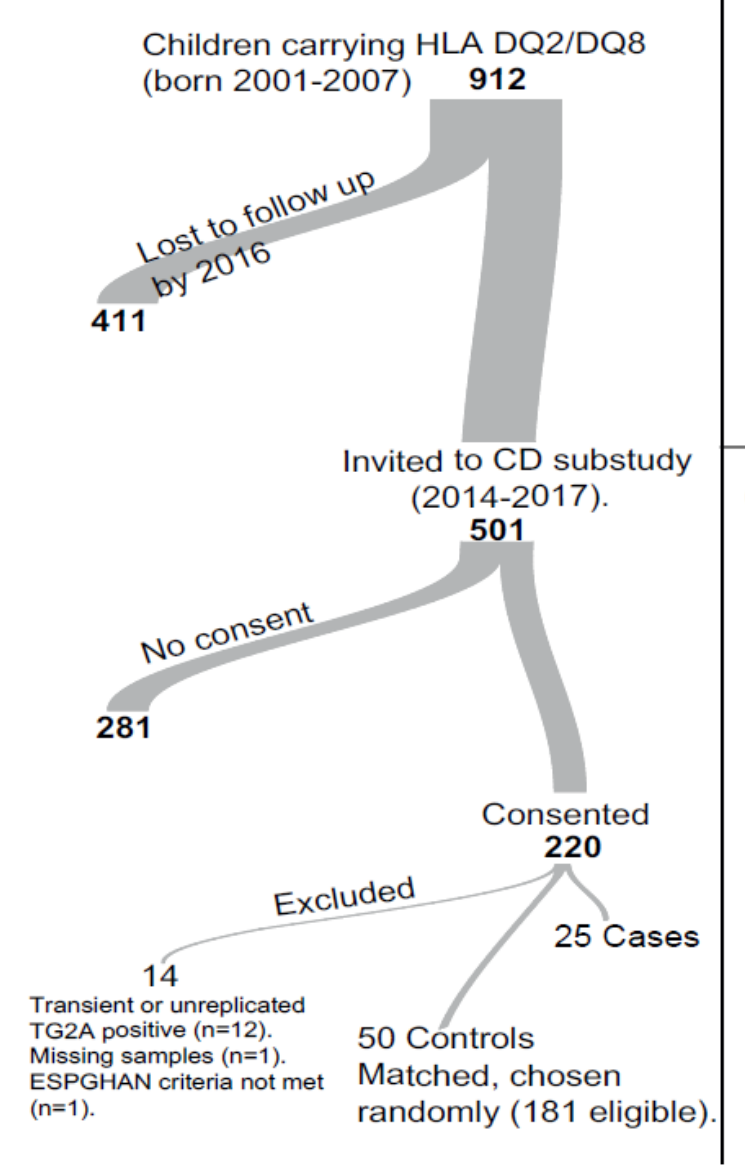

B Follow up Last sample collected was tested for TG2 antibodies

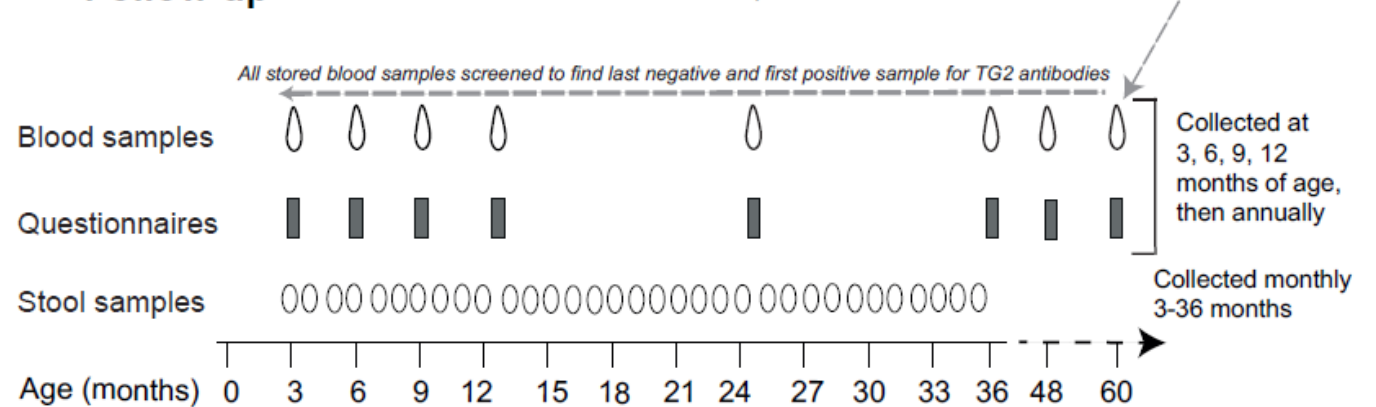

$\begin{array}{llllllllllllllll}\text { Age (months) } & 0 & 3 & 6 & 9 & 12 & 15 & 18 & 21 & 24 & 27 & 30 & 33 & 36 & 48 & 60\end{array}$

\section{Analysis}

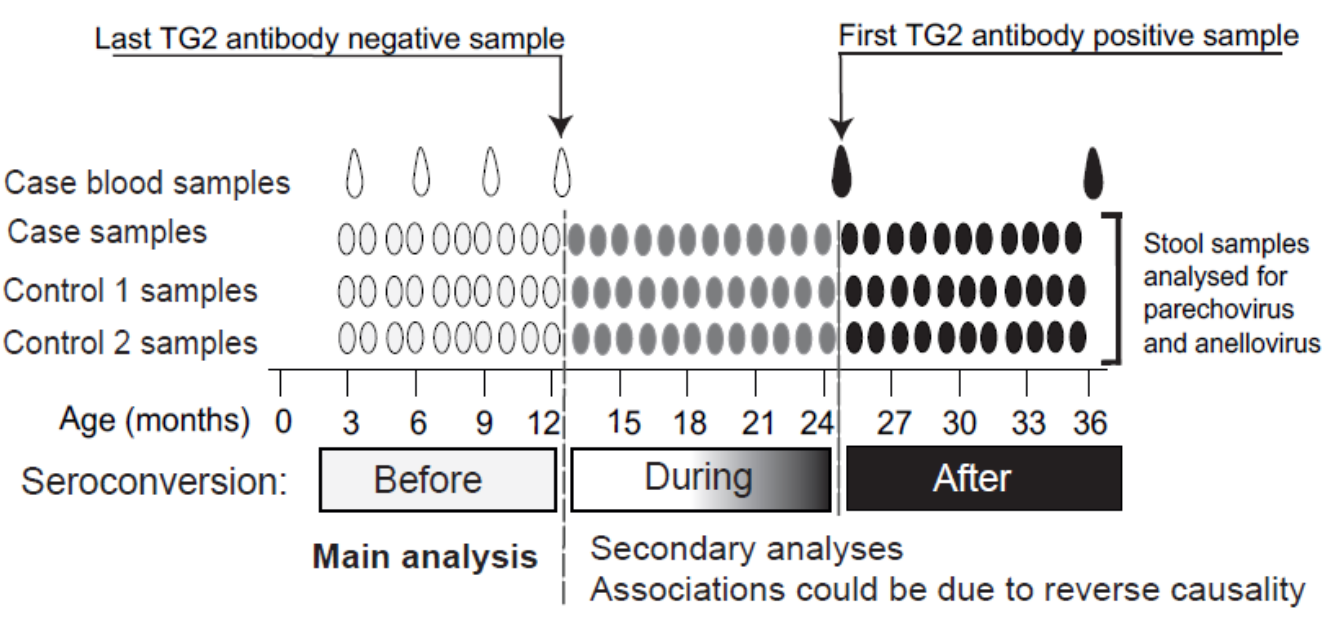

Figure 1: Study design. A flowchart of the current study (A). An illustration of the follow-up and TG2 antibody testing in the study (B). An illustration of the main and secondary analyses in the study (C). R (version 3.6.1, R core team 2018), package riverplot[43] was used in the generation of panel A. 